\title{
Remediating Polluted Soils Using Nanotechnologies: Environmental Benefits and Risks
}

\author{
Gabriela Medina-Pérez ${ }^{1}$, Fabián Fernández-Luqueño ${ }^{2 *}$, Edgar Vazquez-Nuñez ${ }^{3}$, \\ Fernando López-Valdez ${ }^{4}$, Judith Prieto-Mendez, Alfredo Madariaga-Navarrete ${ }^{5}$, \\ Mariana Miranda-Arámbula ${ }^{4}$
}

\author{
${ }^{1}$ Transdisciplinary Doctoral Program in Scientific and Technological Development for Society, \\ Cinvestav, Zacatenco, Mexico City, Mexico \\ ${ }^{2}$ Sustainability of Natural Resources and Energy Program, Cinvestav-Saltillo, Coahuila de Zaragoza, Mexico \\ ${ }^{3}$ División de Ciencias e Ingenierías, Universidad de Guanajuato (UG) Campus León, León, Gto., Mexico \\ ${ }^{4}$ Instituto Politécnico Nacional, CIBA-IPN, Tepetitla de Lardizábal, Tlaxcala, México \\ ${ }^{5}$ Autonomous University of Hidalgo State, Academic Area of Agricultural and Forestry, Tulancingo, Hidalgo. México
}

Received: 9 January 2018

Accepted: 20 March 2018

\begin{abstract}
Since engineering nanoparticles (ENP) have been developed for using in industry and human commodities, is common to find their wastes and by-products from industrial chemical reactions, and it is also possible to find incidental nanoparticles in the environment. Currently, the remediation of polluted soils using nanotechnologies has become an emerging area with a huge potential to improve the performance of traditional remediation technologies. However, environmental concerns have also emerged regarding human and environmental health when nanotechnologies are released to ecosystems. The goal of this manuscript is to highlight the environmental benefits and risks that arise when nanotechnologies are used to remediate polluted soils. We searched Web of Science and Scopus in order to get latest updated information and patents pertaining to developments in the field of nanotechnologies for decontaminating soils. It has been determined that soil nanoremediation has some advantages, but it also has some disadvantages related to the final disposal of nanoparticles, nanomaterials, or nanodevices. Will some nanotechnologies be our pitfall? Nanoparticle toxicity has to be assessed and the standardization of techniques should be set by scientists and decision-makers worldwide. Cutting-edge knowledge regarding the use of nanoparticles to decontaminate soils has to move forward, but environmental quality, human health, and social welfare should also be ensured.
\end{abstract}

Keywords: ecological risk, engineering nanoparticles, environmental concerns, remediation, soil pollution, sustainability and social welfare, sustainable development

*e-mail: cinves.cp.cha.luqueno@gmail.com 


\section{Introduction}

Plants perform many ecological functions in their environments, and they shape the life in the environment where they live. Living things in the world are directly or indirectly dependent on plants [1-6]. The ability of plants to fulfil their functions primarily depends on the availability of appropriate climatic and edaphic conditions [6-9]. Therefore, soil is a necessary condition for plant existence.

Soil is defined as the part of the solid earth that has been altered by the loosening of the earth, humus formation, and chemical decomposition, and by the transportation of humidification and chemical decomposition products [7, 10-19]. However, when it is examined in detail, soil is a complex structure and the biological and biochemical processes in it are the basis of the terrestrial ecosystems [7, 8, 10-19]. In this respect, it is imperative to examine health changes of the soil and to determine its relationship with the plant. Also, both improving the soil quality throughout soil conservation and remediation technologies, and reducing the conditions that jeopardize soil quality are two critical points to shape the sustainability of soils [20-25].

Currently, advancements in the fields of nanoscience and nanotechnology have delivered myriad possibilities for consumer product applications. Many of these products have already migrated from laboratory working tables toward store shelves and e-commerce websites. However, research regarding nanoparticles, nanomaterials, or nanodevices is still ongoing regarding their potential effect on human and environmental health [20-21].

Also, new areas of knowledge have emerged along with nanoscience and nanotechnology such as nanotoxicology, nanobiotechnology, nanoremediation, etc. However, cutting-edge knowledge regarding the use of nanoparticles to decontaminate soils is being built right now worldwide. It is well known that knowledge regarding nanoremediation has to move forward, but it is also well known that this huge challenge requires the participation of scientists from many areas of knowledge [22-23]. It has been reported that nanoparticles might increase polycyclic aromatic hydrocarbon (PAH) dissipation in a polluted soil when it is amended with wastewater sludge, polyacrylamide, and nanoparticles [23-25]. Besides, the use of nanotechnologies to decontaminate soils has frequently been published during the current year [26-28]. However, the development of the appropriate use of nanotechnologies for remediating polluted soils has to be achieved as soon as possible in parallel with a comprehensive understanding of the human and environmental riskbenefit balance [29].

Soil contains many kinds of organic and inorganic particles in the nanoscale or colloidal range, i.e., $<100$ $\mathrm{nm}$ [30]. However, a lot of nanoparticles, nanomaterials, or nanodevices have been used to dissipate soil pollutants notwithstanding the interactions of nanoparticles with the soil environment that have not been well studied, i.e., the movement, fate, and bioavailability of nanoscale materials into soil matrix are still unknown. In addition, the increasing entry into soil of engineered and anthropogenic nanoparticles has raised concerns about their potential adverse effects on human, animal, or ecosystem health.

The goal of this review is to highlight the environmental benefits and risks that emerge when nanotechnologies are used to remediate polluted soils. Therefore, this manuscript shows an updated discussion about the nanoremediation of polluted soils and its human and environmental risks or benefits.

\section{Soil Environment}

The environment of soil is a complex system from several points of view. For example, the soil matrix is a tri-phasic system, i.e., it has solid, liquid, and gas phases or states. Additionally, there are biotic and abiotic interactions, the biotic interactions by microorganisms such bacteria, virus, fungi, protozoa, and amoebas, mainly, and as multicellular organisms are nematodes, arachnids, mites, earthworms, etc. The abiotic interactions are by mineral elements such as alkaline and transition metals, particularly.

Soil microorganisms play important roles in plant growth and agroecosystem (they are involved in soil ecosystem, in the decomposition of organic residues, and they are the key to driving nutrient cycling in soils, such as biogeochemistry cycling of carbon, nitrogen, phosphorus, and potassium, mainly). The extensive use of nanoparticles (NPs) will increase their concentration into the soil and consequently their environmental effects and ecological risks [31], by manufactured NPs for products with a wide industrial, commercial, medical, and agricultural applications [25, 32]. Some metal or metal oxide NPs have been found to be highly toxic toward soil microorganisms and to have a high impact on soil microbial species diversity [24, 32]. However, there are reports about beneficial effects of some NPs, as stated by $\mathrm{He}$ et al. [32], who reported that the changes in abundances of bacteria, eukaryotes, and ammonia-oxidizing bacteria measured by realtime polymerase chain reaction (Real-Time PCR), also known as quantitative polymerase chain reaction (qPCR), studying the effects of metal or metal oxide nanoparticles on soil microbial metabolic activity and the key ecological functions. It was found that $\mathrm{AgNP}$ (at $0.1,1$ and $10 \mathrm{mg} \mathrm{kg}^{-1}$ soil) amendments decreased soil microbial metabolic activity, nitrification potential, and the abundances of bacteria and ammonia-oxidizing bacteria. On the opposite, it was found that FeO-NPs had positive effects on soil microbial metabolic activity (at 1 and $10 \mathrm{mg} \mathrm{kg}^{-1}$ soil) and soil nitrification potential (at 0.1 and $1 \mathrm{mg} \mathrm{kg}^{-1}$ soil) [32].

We observe that concerns are about the synthesis and production of NPs (unpublished data), but not on 
the toxicological, environmental, exposure, or disposal effects on humans, animals, and plants. So, the view about the extensive application of NPs under the non-regulated condition of many applications must be a concern.

\section{Nanoscience and Nanotechnology as Useful Tools in Agriculture}

Nanotechnology is a multidisciplinary science research area that basically works in the design, characterization, fabrication, and application of structures and constituents, and is created by the controlled size manipulation and shape at the nanometer scale (atom and molecular, less than $100 \mathrm{~nm}$ ) producing structures, components, and systems with at least one feature or new characteristic or higher property [33]. These new materials are engineered intentionality looking for advantages over traditional materials. The nano-sized particles have reached a big amount scale production, estimated to be $260,000-309,000$ metric tons in the 2010 and about $8-28 \%, 0.4-7 \%$, and $0.1-1.5 \%$ were calculated to end up in environmental containers: soil, water bodies, and atmosphere, respectively [34].

According to the report published by FAO in 2013 on the state of the art of nanotechnology in food and agriculture, research was conducted for ten years seeking to achieve sustainability and solutions to environmental problems. Such investigations focus on: the smart release of active ingredients (disease management and crop protection), minimizing the loss of nutrients in fertilization and increasing performance, and producing bio-nano compounds from traditional crops [35].

The need to increase food production is projected to reach 9.9 billion people by 2050 [36]. A growing population requires the optimization of resources (soil, water, inputs) and the conditioning of damaged soils for agriculture uses. Declining oil reserves will generate a transition to the production of energy crops gradually. As a result of FAO in the 2009 forum of experts, "How to feed the world in 2050," it will be necessary to increase grain production by $70 \%$ by 2050 . Nanotechnology can supply tools in modern agriculture and become useful in the solution of future problems of food and energetic demand with a sustainable approach (Fig. 1).

Our knowledge about the interactions of ENMs with soil is very limited, and because of the complexity of this system, there is still a long way to completely understanding the behavior of anthropogenic nanoparticles. The last fifteen years of soil studies are encouraging in transcendental issues: improving fertility, reducing degradation, attenuation or degradation of contaminants, and developing nutrient and pollution sensors [37, 38].

The development of nanocomposites and nanoencapsules suggests that controlling amounts of active ingredients needs to be taken up in a stable form throughout crop growth, avoiding overdoses, and reducing input and waste [39]. These active ingredients can be fertilizers [40, 41], herbicides [42-44], plaguicides [45, 46], or growth promotors [47], and their rationalization and control of the amount of application could be effective in reducing the overall costs of cleaning up highly contaminated places by eliminating the need for treatment and disposal of contaminated soil [48].

About improving and maintaining soil conditions, there are published on the web several reviews about applications of nanomaterials that are potentially useful $[39,49]$. Progress has been documented in retaining nutrients since it is known that only a small percentage of the fertilizer applied is used by crops, the rest is lost by washing, processing or mineral retention, and the use of nanofertilizers allows the nutrient movement in the rhizosphere, improving composition and doses. Today it is possible to design NPs or nanoscale vehicles to reach the roots and enhance the uptake of beneficial molecules. These vehicles could also look for specific soil particles and repair damage [50].

Bin Hussein et al. [51] reported on utilizing zinc and aluminum hydroxide-based composites as a coating to slow the liberation of nutrients. Kottegoda et al. [52] encapsulated urea hydroxyapatite nanoparticles in wood, where they liberated nitrogen during 60 days versus 30 days of commercial fertilizer. There is a list of

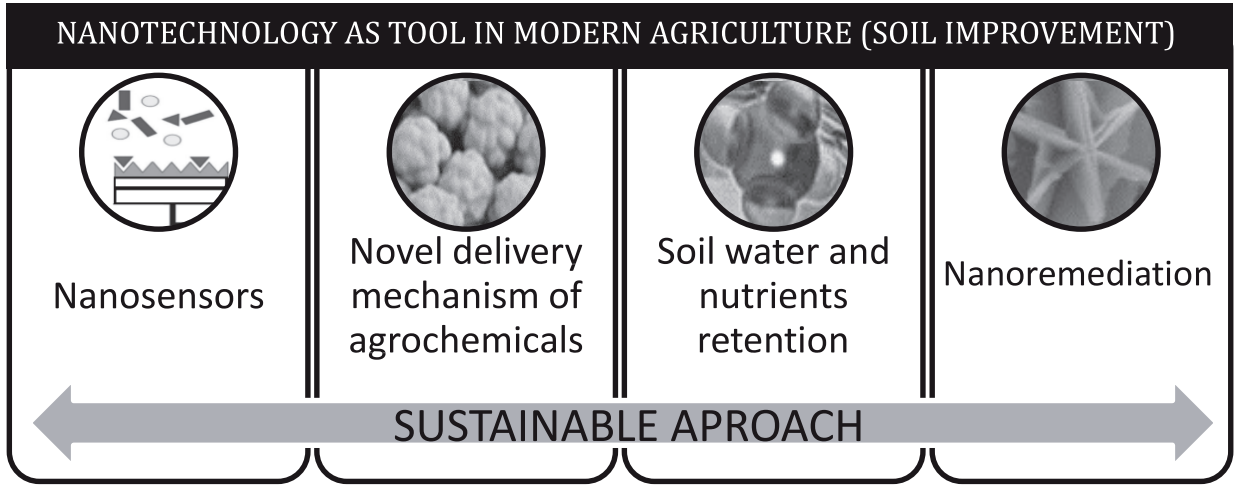

Fig. 1. Technological advances aiming to improve soil quality and reduce its pollution through nanotechnological applications . 
patented products, one of them based on a mixture of nitrogen, phosphorus, potassium (NPK), micronutrients, mannose, and amino acids designed for grain crops [53]. The loss of nitrogen by leaching is well known, which is the cause of eutrophication of water; this problem was less present when fertilizers were coated by nanomaterials like plastic-starch mixtures of composites [54].

Water retention of nanomaterials has been developed in nanoclays, nanozeolites, and nanohydrogels [55]. Sekhon [56] showed a complete review of them and their novel properties. Nanoclays, made of polyacrylamide polymer, is a nanocomposite that presents high water absorbency and water retention when coated with zinc. This is an important characteristic because they could be applied to rainfed crops [57]. Recent research on the present year by Mahfoudhi and Bouf [58] designed nano-hydrogels based on cellulose nano-fibrils (CNFs) and polyacrylic acid-co-acrylamide. The obtained structure caused the system to release urea simulating a fertilizer. This last report shows the combined properties of nanomaterials to enhance soil conditions. Kottegoda et al. [59] drank hydroxyapatite nanoparticles (obtained from $\mathrm{H}_{3} \mathrm{PO}_{4}$ ) between spaces of clay platelets and they achieve a slow release of phosphate, the same authors included modified cellulose for the same protective function. Liu and Lal [60] produced synthetic apatite nanoparticles as the form of phosphorus slowly loaded for soybean plants (Glycine $\max$ L.).

Mesoporous silica (MSN) are used to load pesticides, this coat protects the active ingredient (avermectin) from photodegradation, and dosified slowly thus they remain active longer [61]. Some nanomaterials are useful in crop protection and eventually become "soil friendly" due to their biodegradability. Khot et al. [62] was encapsulated inside a mixture of chitosan and alginate with two active substances (nano-imidacloprid in combination with $\mathrm{Ag} / \mathrm{TiO}_{2}$ ) for plague control. As a result, the residues of the formulation were degraded in the soil after eight days of application. Zhao et al. [63] presented a complete overview about the bionanocomposite, and the proposal has the advantages of utilizing biodegradable polymeric matrices based on proteins or starch in order to protect fertilizer formulas and nanobioplastics production. The application of biochar has shown interesting results, including soil amendment and sorption of several undesirable residues $[64,65]$.

In respect to the nanosensors, there are advances and improved features compared with the common sensors. The nanosensors are made for sensing 100 $\mathrm{nm}$ or fewer dimensions. Nanotubes, nanoparticles, nanocrystals, or nanowire send a signal in response to the presence of other composites of similar size. The big surface reaction of nanomaterials gives back a rapid reaction, enhancing the sensitivity of the detection system; installing nanosensors in fields allows the farmer to know in real time the conditions of soil and very early detection of potential problems such as water deficit and soil nutrient demand. It could be an advantage enhancing precision farming in the next years in order to improve the reactions in front of agronomic challenges $[24,25,66]$.

\section{Natural and Anthropogenic Occurrence of Nanosized Materials in Soil}

Nanoparticles (NP) are considered to be the building blocks for nanotechnology, and refer to particles with at least one dimension $<100 \mathrm{~nm}[22,24,25,67]$. On the other hand, the nanomaterials (NM) are defined as engineered materials with a least one dimension in the range of $1-100 \mathrm{~nm}[22,68]$. Soils are a repository of many engineered and natural nanoparticles prevenient of many industrial and environmental applications, and this has originated discussions concerned its effect on biological systems, especially on human health and about its role on geochemical processes [23, 69] and impacts on the ecosystems [25, 70].

\section{Nanoparticulate Materials in the Environment}

As it was said before, these nanomaterials are a complex mixture of natural and anthropogenic nanostructures [71]. Nanoparticles had reached the environment before the field of nanotechnology emerged. The most important sources of natural nanoparticles have been present as geogenic dust [72], volcanic soot, and carbonaceous particulate matter [73], and sub-products of combustion processes such as power generation and transportation [74], and erosion [75]. Since the nanoparticles have been developed for use in industry and human commodities, it is common to find wastes and sub-products from industrial chemical reactions [76], wastewater treatment plants [77], and landfill lixiviation [78], among other activities.

The presence of the nanomaterials is not only associated with their natural origin; it is also possible to observe the non-intentional release due to manufacturing or transportation [79]. Because of the diversity of the nanotechnology applications, the nanoparticles may enter the environment through many pathways, for instance emissions to the atmosphere may result in deposition to soils and water, the use or nanotechnologies for remediating polluted soil, it may also enter as a result of the wastewater treatment, as a sub-product of water treatments sewage sludge or accidentally during spills. Despite knowledge about the release pathways, some nanoparticles present in the environment are still unknown [80].

In most cases the dispersion medium of nanoparticles that come in close contact with man of other living components is air or water, therefore the soil is the main receptor of most of the either natural and anthropogenic nanoparticles via direct release or because of the deposition of nanoparticles [81]; this 
complex multiphasic matrix releases the nanomaterials to plants and animals, and greatly affects human health [82].

\section{Natural Nanoparticles}

According to Lungu et al. [83], earth, cosmic, and weather-dependent phenomena on the planet produce particulate matter that is lifted in the air through volcanic eruptions, air currents generated by storms or strong winds, the disintegration of meteorites entering the atmosphere, or the accumulation of cosmic dust. The evolutionary development of hominids has been accompanied by the presence of natural nanominerals and mineral nanoparticles [84].

\section{Humic and Fulvic Acids}

The particles belong to the clay fraction in the soil and have been classified as particles smaller than 2 micrometers; however, it is possible to identify colloidal particles in size range of 1 to 100 nanometers, allowing for the inclusion of this fraction to the nanosize scale.

As a ubiquitous component in soil, the organic matter may influence greatly some properties of the nanoparticles such as surface speciation and electric charge [85], affecting their aggregation/deposition properties. Their biological importance is based on structural support for microbial communities and its function as a nutrient provider [86]. On the other hand, the fulvic and humic acids participate as acceptors and donors of electrons for the biodegradation of contaminant compounds [87]. In some cases, they are involved in processes of contaminant transportation and can enhance the chemical degradation [88-90]. The mobilization of NPs in soil is driven by its interaction with the organic matter, and it can affect superior organisms such as plants, animals, and finally humans [91].

\section{Generic Geogenic Oxides}

The primary and permanent reservoirs of nanoparticles and nanomaterials are deserts. Shi et al. [92] reported that about $50 \%$ of the minerals in aerosols in world air come from deserts. Although the composition is variable, the most important group of geogenic nanoparticles are formed by oxides, hydroxides, and oxyhydroxides of metallic elements such as $\mathrm{Al}, \mathrm{Fe}$, and $\mathrm{Mn}$, which were formed by weathering of silicates and microbial pathways [93].

Some special characteristics are related directly to the origin, and its distribution in the environment is variable. For example, the aluminum nanostructures can be found in soil as gibbsite and boehmite, generated by geological processes. The manganese nanoparticles are formed during bioprocesses in soil bacteria and fungi [94]. Also, the iron hydro oxides are among the most abundant natural nanoparticles in soil, developing an important role in the process of nutrients absorption, and acting as exchangers of molecules due to its electrostatic charge [30].

\section{Anthropogenic Nanoparticles}

All the human activities have an impact on the environment. The development of new materials and particles for diverse applications has driven into a new era: the nanoscale dimension. The anthropogenic sources of nanoparticles and nanomaterials are classified as primary due to mineral exploitation and the secondary given by industrial activities (stationary or mobile sources) $[83,95]$.

The presence of primary nanoparticles is localized in places with activities such as fossil fuel exploitation, ferrous, and non-ferrous mineral extraction and exploitation of natural materials for construction. The nanoparticles prevenient from primary sources are not as harmful as the nanoparticles prevenient from secondary sources.

\section{Carbon Nanotubes}

Probably, the most relevant example is given by graphene, which has an excellent thermal and electrical conductivity and is released to the environment as a result of the discharge of the materials containing this material (plastics, electrodes, sensors, automotive components). It has been reported that the nanomaterial may behave differently in the environment and it could affect the biogeochemical and microbial dynamics in soil [96].

\section{Engineered Metallic Oxides}

Most of the metallic nanoparticles have been developed for the cosmetic sector [97], catalyzers in industrial processes [98], medical diagnosis [99], delivery of drugs [100], and bioremediation of polluted soil and water [101, 102].

Oxide metallic nanoparticles have been elaborated upon as both individual oxides $\left(\mathrm{ZnO}, \mathrm{TiO}_{2}, \mathrm{CeO}_{2}\right.$, $\mathrm{CrO}_{2}, \mathrm{MoO}_{3}$, and $\left.\mathrm{Bi}_{2} \mathrm{O}_{3}\right)$ and binary oxides $\left(\mathrm{BaTiO}_{3}\right.$, $\mathrm{LoCoO}_{2}$, and $\left.\mathrm{InSnO}\right)[103,104]$, and according to their composition, variable adverse effects in soil have been reported.

\section{Inventory of Nanowastes in the Environment}

Despite the commercial and technological importance of NP and NM, its presence - natural, intentional, or accidental - in the environment is still unknown. However, some efforts have been made to offer a clear idea regarding the applications of nanomaterials in consumer products and its presence in the world market. 
Since the presence of nanomaterials in the market implies its release to the environment, this information has been taken for having a wider landscape of the nanomaterials presence in the environmental matrixes, such as soil and water. Vance et al. [23] reported that around $64 \%$ of carbonaceous nanomaterials are embedded in solid products, whereas products of all other compositions are suspended in liquid. Of the few bulk nanomaterials that are available for purchase by consumers, the largest group (42\%) consist of metal oxide nanomaterials. Metal and metal oxides were also the largest compositions for surface-bound particles and those suspended in liquid products.

According to Chatterjee [105], there are eight categories where the nanomaterials are majorly used, in increasing order: goods for children, appliances, automotive, cross-cutting, food and beverage, electronics and computers, home and garden, and health and fitness. Some examples are given as follows: $\mathrm{TiO}_{2}$ and $\mathrm{Ag}$ nanoparticles are used to confer antimicrobial protection $[22,106]$, and $\mathrm{TiO}_{2}$ and $\mathrm{SiO}_{2}$ are used to provide protective coatings and for environmental treatments [107]. Cosmetic products contain silver, titanium, and gold nanoparticles [97] and nano-organic compounds.

A geographical inventory was reported by Chatterjee [105], where the number of products was registered by region, placing the United States of America as the first producer of 247 products, followed by East Asia (China, Taiwan, Korea and Japan) with 123 products. Also, Europe (U.K., France, Germany, Finland, Switzerland, Italy, and Sweden) with 76 products and others (Australia, Canada, Mexico, Israel, New Zealand, Malaysia, Thailand, and Singapore) with 27 products. This distribution is directly linked to the laws and regulations for each country or region [108].

Some other partial and complete inventories were done by Maynard et al. [109], Kannan et al. [110], and Berube et al. [111]. It is clear that this is useful for policy makers focused on the regulatory terms of consumers and producers of these products. Additionally, it is also important for having a clear idea about where and how nanomaterials are present in the environment after being used by consumers, allowing us to know and understand the routes by NM and NP arrived at the environment. The subsequent step would be to use tools such as life cycle analysis (LCA) to evaluate its impact on the environment $[34,112,113]$.

\section{Nanotechnologies to Remediate Soils}

Nanotechnology is a virtually new environmental technology, and when applied to contamination problems it is known as nanoremediation [114]. This has recently been used for the treatment of hazardous waste sites. Lately, the use of nanotechnologies for environmental remediation has received significant attention from the scientific community [115], specifically in use for environmental remediation $[24,25,115]$, in spite of that is recent technology field.
In 1996, Gillham was the first investigator who presented the idea of utilizing zero valent iron in permeable barriers reactive, based on their experience with the use of nanomaterials in decontamination with water-halogenated pollutants [116]. Some authors have synthesized nanoparticle zero-valent iron from chemical synthesis, while others from various extracts of green leaves, the same as those used for treating contaminants in aqueous solutions. In many cases the use of nanoparticles were effective to degrade contaminants such as organic halogenated hydrocarbons [117, 118], nitrates, heavy metals [119-121], insecticides, and dyes $[122,123]$.

There are very few studies that apply nanoparticles technology for the remediation of contaminants in soil, the research in this field has been used more for the decontamination of water or aqueous solutions [124]; according to the literature, the nanoparticles have the ability to adsorb and facilitate degradation of pollutants through various mechanisms such as redox reactions, surface processes, adsorption, ion exchange, surface complexation, and electrostatic interaction [125].

Shi et al. [124] tested nanoparticles zero-valent iron (nZVI), and iron nanoparticles zero valence on a matrix of bentonite (B-nZVI), in the removal of $\mathrm{Cr}$ (VI) in water and soil solution contaminated with this metal. As a result, they found that nZVI nanoparticles became more effective when the bentonite was introduced (B-nZVI) as carrier material due to the reduced aggregation and increased specific surface area; besides, they obtained a high rate of removal of $\mathrm{Cr}$ (VI), which increased directly proportional to temperature, and the amount of B-nZVI, but decreased as the $\mathrm{pH}$ increased [124-126]. In this project the use of nanoparticles B-nZVI for removal of $\mathrm{Cr}$ (VI), had great utility due to having a high surface area that is associated with its high reactivity, allowing it to work like an excellent agent capable of transforming, and degrade contaminants that use nanoparticles B-nZVI for removing $\mathrm{Cr}$ (VI) [124]. Likewise, the removal of other pollutants such as chlorinated organic compounds, pesticides, phenols, amines, and organic acids through such nanoparticles has been studied [126].

Other studies on this subject have shown that polybrominated diphenyl ethers, which are a class of environmental contaminants that can easily accumulate in the soil, can be degraded with zero valent iron nanoparticles immobilized in silica microspheres $[127,128]$. The evaluation of the degradation decabromodiphenyl ether, from an aqueous solution with tetrahydrofuran (THF), was analyzed by Qiu et al. [127] and found that it was effective in a solution of THF/water to temperature and environmental pressure. Moreover, Xie et al. [128] evaluated this degradative ability to remove soil decabromodiphenyl ether, obtaining results that revealed that the removal efficiency or the performance of elimination of the ether of decabromodiphenyl was $78 \%$. It was higher than the biomass of untreated plants with nanoparticles [128]. 
In other experiments, the growth of cabbage mustard in the presence of $\mathrm{Cr}$ (VI) and using iron nanoparticles supported on bio-carbon was evaluated; here the phytotoxicity of $\mathrm{Cr}$ (VI) was analyzed, and they found that the growth of cabbage mustard increased by treatment with nanoparticles, and also effectively reduced $\mathrm{Cr}$ (VI). Remediation tests $\mathrm{Cr}$ (VI) and total chromium (Cr) showed that immobilization efficiency was $100 \%$ and $91.94 \%$, respectively, by applying $8 \mathrm{~g}$ per $\mathrm{kg}$ of soil [129].

Also, $\mathrm{SiO}_{2}$ nanoparticles coated with a lipid derivative of choline have been used in the bioremediation of polycyclic aromatic hydrocarbons (PAHs) [130]; also, these nanoparticles were used coated with a lipid derivative of choline in the bioremediation of PAHs. Other nanomaterials that have been used are iron sulfide stabilized with carboxymethylcellulose; similarly, they were tested for immobilizing $\mathrm{Hg}$ in soils highly polluted with this metal [130].

Trujillo and Reyes [125] described the efficiency of zero valent iron nanoparticle to the remediation of contaminated aqueous solutions with ibuprofen in soils; being able to degrade ibuprofen in 54-66\% of the initial amount in aqueous solutions and they obtained similar remediation efficiencies in the sandy soils. Olson et al. [131] conducted studies on soil with nanoparticle bivalent metals (Fe and $\mathrm{Mg}$ ) to reduce the concentration of polychlorinated biphenyls (PCB) in soils achieving a reduction of 56\% of the average concentration of PCBs, with a rate of average degradation of $19 \mathrm{mg} \mathrm{kg}^{-1}$ week $^{-1}$ [131]. Also, phytotoxicity tests conducted on samples of treated soil indicated almost complete restoration of PCB, evaluated based on high levels of germination; the same type of emulsified zero-valent iron was used in in situ treatment of polychlorinated soils, where there was the destruction of 2-clorobifenilo [131].

Other authors have emphasized the need to develop investigations on the ecotoxicity of the soil remedied with the use of nanotechnology [132], especially considering the tests with the use of plants that may be useful as sensitive indicators of soil toxicity [131, 132]. Also, the processes of nanoparticle degradation in the soil and its phytotoxicity need to be researched more, especially taking into account testing with the use of plants that may be useful as sensitive indicators of soil toxicity [133].

Recent research in 2016 refers to the toxicity of some nanomaterials and their effectiveness to interact in soil. For example, Fan et al. [134] studied the mechanism by which nano- $\mathrm{TiO}_{2}$ affects the toxicity of $\mathrm{Cu}$ on Daphnia magna, mentioning that nanoparticles of titanium dioxide $\left(\mathrm{TiO}_{2}\right)$ can affect the toxicity of other pollutants and that the presence of organic matter can influence their combined toxicity. This study also found that the effect of nano- $\mathrm{TiO}_{2}$ on the toxicity of $\mathrm{Cu}$ to $\mathrm{D}$. magna decreased significantly with the presence of acid humic, which implies that the presence of organic matter in soil could decrease the remedial effect of such nanoparticles in the presence of some contaminants in soil. They mentioned that the effect of $\mathrm{TiO}_{2}$ nanotoxicity of heavy metals depends on the adsorption capacity of heavy metals in the nano- $\mathrm{TiO}_{2}$; and absorption and stability in the formation of complex metal-nano- $\mathrm{TiO}_{2}$ and the presence of dissolved humic acids, which affect the ability of nano- $\mathrm{TiO}_{2}$ to accumulate $\mathrm{Cu}$ [134].

Although many types of nanoparticles can be used for soil decontamination, almost all researchers only consider the use of nanoparticles of zero-valent iron for practical field application; it is also interesting to note that most studies refer to decontaminating primarily saturated soils. Only a few studies have addressed the remediation of contaminated - not saturated - soils [135]. The different existing publications in 2016 refer to different experimental parameters and of synthesis of nanoparticles, which makes it difficult to make a comparison between the efficiencies of different used nanomaterials, since they vary in their structure, composition, and morphology, and all this affects adsorptive capacity opposite to similar contaminants, and knowledge of their ability to degrade different types of pollutants is still scarce.

Analysis of the literature highlights the need for more studies on nanomaterials, given the lack of information on the mechanisms of regeneration and reuse, and its large-scale application and effectiveness in treating industrial wastewater real and contaminated soils; nevertheless, existing results to date indicate that this remediation technology represents a good alternative to traditional technologies. Nowadays, little is known about the mechanisms of nanomaterials on the ground, their life cycle, the release of metal ions, and their impacts on different ecosystems. Nanoremediation has different advantages, such as reducing the cost, cleanup time of contaminated sites, and they can be used on a large scale. But it is necessary to make deep studies evaluating the effect of nanoremediation on the ecosystem level in order to prevent any adverse environmental impact.

\section{Effect of Anthropogenic Nanosized Materials on Soil Environment and in the Environment}

\section{Why Nanotechnologies?}

From the definition of nanotechnology, it is possible to observe the many benefits that this technique can bring to sciences. This technology has been reported to be beneficial in medicine [136-140], physics [136, 141], genetics [142-144], and, most recently, in environmental sciences, among many other areas [123, 145-147]. We must highlight the fact that nanotechnologies have been reported as reliable [148], feasible [140], promising [149], practical [150], precise [151], cheap and effective [152], emerging [153], powerful [154], and economically feasible [155]. 


\section{Nanotechnology Examples in Environmental Sciences, Specifically for Soil Remediation}

Nanotechnology in environmental sciences is still new, and many of the results of the research in this field are still in the process of being marketable in the form of nanoproducts. It was not established with certain clarity what was exactly a nanoproduct in the environmental area. Nevertheless, Cinelli et al. [156] established the criteria for evaluating the sustainability of nano products. The authors identified six main areas of environmental nanoproducts, including environmental impacts. Thus, we should include nanotechnologies for soil remediation under the already cited category. Examples of the use of nanoproducts in environmental sciences are: i) the ones reported by Ali et al. [157], for the applications on photocatalytic degradation of organic pollutants; ii) the study of $\mathrm{Li}$ et al. [158] in the area of propulsion; iii) studies of Scognamiglio et al. [159] in biosensor technology for endocrine-disrupting chemicals; iv) studies by Elango and Roopan [160] for the degradation of methylene blue, an important water pollutant; and v) studies by Begum et al. [161] for the quick sensing of environmental stimuli (as $\mathrm{pH}$, ion strength, biological molecules). More studies in nano molecules for sustainability procedures are the ones from Li et al. [162] for the construction of hydrogels for bioanalysis purposes, and the studies of Kannan et al. [110] describing the use of hydrothermal carbonization materials that convert wet biomass into a cool-like material with applications in the field of energy. Additionally, studies by Pereira et al. [163] on the use of microorganisms during the biosynthesis of metallic nanoparticles and studies by Bogdan et al. [164] reporting the creation of nanomaterials with selfdisinfecting and self-cleaning surfaces, have been described in the literature. It has to be noted that many of them are in experimental phases and cannot be found in the market.

More recent studies show some applications of this nanotechnology in the area of agriculture. Peters et al. [165] report the in-development applications of nanoencapsulates and nanocomposites for food and feed additives, biocides, pesticides, and food contact materials. Also, Ibrahim et al. [166] report the application of nanomaterial as amendment agents for phytoremediation purposes and the use of stabilizers to enhance their performance. Nathanail et al. [29] indicated the existence of the NanoRem European Research project, which finances studies directed to develop the appropriate nanotechnology for contaminated soil remediation. They report the injection of nanoparticles into contaminated groundwater to result in a minimal level of risk because of the peculiar pathway these particles unleash while unfolding the contaminant macromolecules. Das et al. [145] reports the increasing use of diverse materials in their nano form (iron, titanium, dioxide, silica, zinc oxide, carbon nanotubes, dendrimers, polymers, etc.) to decontaminate soils.
A comprehensive review from Dadrasnia et al. [167] exposed the remediation options available in the case of oil/spill contamination with the emphasis on biological treatments via advances in nanotechnology (supplement addition and phytoremediation). In the area of simulation, Wang et al. [139] reported the use of the proposed coarse-grained molecular dynamics simulation, useful for studying the water/oil/solid systems, which could be of a broader use in industrial applications, including environmental sciences. This proposed model is expected to promote the development of this type of simulation to study multiphase systems. Interesting is the report from Husen and Siddiqi [168] describing the use of plants or their extracts, providing a biological system route for the generation of several metallic nanoparticles. This last represents a more eco-friendly route for the production of these useful nanoparticles. The so-called photosynthesis represents a viable route for the production of metal and metal oxide nanoparticles, allowing a controlled synthesis with well-defined size and shape, with broad application in industry, including soil bioremediation.

More specifically, nanotechnology in soil remediation and bioremediation has been recently introduced as a worthy technology in the last decade. The study by Nguyen et al. [75] generated a new strain of the genus Cronobacter, which have been studied for their capacity to remove selenite with $100 \%$ efficiency by taking up electrons from an electrode that performs selenite reduction. The use of produced nanoparticles by microbial selenite reduction may represent an alternative for industrial recovery purposes. An extensive investigation from Fernandez-Llamosas et al. [169] report the isolation of Azoarcus bacterial genus as a physiologically versatile group of beta proteobacteria. It is defined as a facultative anaerobe genus combining the ability to anaerobically and aerobically biodegrade a wide range of aromatic compounds, including toxic hydrocarbons (toluene and m-xylene) while and endophytic lifestyle in the root of rice. Authors conclude the technique to be suitable for more sustainable agricultural practices in bioremediation strategies.

Pollmann et al. [170] reported the so-called biohydrometallurgical processes, which include the operations of biomining, bioleaching, and biooxidation, facilitating the degradation of minerals. Other interesting processes are bioaccumulation, bioflotation, bioprecipitation, and biomineralization, which are processes that have been very well studied but with recent practical applications because of the rapid development of novel techniques as nanoscience technologies. The mentioned processes are thought to be an environmentally friendly and efficient alternative for industrial applications, including contaminated soil bioremediation.

Interesting is the concept of bioprospecting, introduced by Beattie et al. [171]. Benefits of this technique include unrespecting products useful for industry, chemicals, metabolic pathways, structures, 
and materials. To 'bioprospect' a remediation technique for soil remediation would involve the decrypting of the involved pathway in the mineralization of soil pollutants, which can be strongly benefited by the support of nanotechnologies. Emtiazi et al. [172] reported the use of nanofilters and nanofilters plus a microbe to be 45 and $91 \%$ more efficient, respectively, for the removal of Methyl ter-butyl eter, used in gasoline and polluting soils. Bozarth et al. [173] have reported a source of nanotechnological procedures for bioremediation of contaminated soils, which includes the diatom molecular biology as well as the culturing conditions and photobioreactor efficiency. The future in soil bioremediation with the use of nanotechnologies is the one represented by experiments from Juwarkar et al. [174], reporting cell isolates of Bacillus sphaericus (named JC-A12) from a uranium mining waste pile. The isolates can accumulate toxic metals ( $\mathrm{U}, \mathrm{Cu}$, $\mathrm{Pb}, \mathrm{Al}, \mathrm{Cd}$ ) as well as precious metals ( $\mathrm{U}, \mathrm{Cu}, \mathrm{Pd}(\mathrm{II})$, $\mathrm{Pt}(\mathrm{II}), \mathrm{Au}(\mathrm{III}))$. The special capabilities of the cells are highly interesting for the cleanup of uraniumcontaminated wastewaters and soils. An extensive overview of nanotechnology-supporting and -improving bioremediation procedures is presented by Juwarkar et al. [174]. Successful case studies from this last include bioremediation studies in vadose soils, bioremediation of contaminants from mining sites, air spraying, slurry phase bioremediation, and phytoremediation from pollutants and heavy metals, as well as vermicomposting.

\section{So, are Nanotechnologies a Sustainable Procedure for Soil Remediation?}

A commonly accepted definition of sustainability is "the ability to pursue an economic prosperity maintained over time while protecting the global natural systems and providing a high quality of life for people" [175]. From the results of the research of all the cited authors in this review, we want to propose an affirmative answer to the original question, but the answer has several edges, i.e., social, environmental, and economic concerns regarding nanoremediation have to be attended in order to improve the technologies, decreasing costs and shaping a sustainable future. Procedures and researchers cited in this review claim that the results are useful for the production of commercial applications (economic prosperity) and also claim that the procedures are "environmentally friendly" to protect natural systems worldwide.

It should not be forgotten that all natural systems are self-regulated but, in most cases, the pollution's concentration is far above the environment's natural ability to decontaminate by itself, i.e., natural attenuation is not always possible. In addition, to our best knowledge, there is no evidence regarding the natural attenuation of nanopollutants.

Our activities, and we as humans, have changed the global natural balance. Then, nature and wisdom are providing us with tools to face up to pollution and degradation through nanotechnology. All we have to do is to understand the system where we are working - especially in the area of soil remediation. If we create more eco-friendly technologies for agricultural procedures, improve industrial processes, increase the regulatory framework, and educate the society, remediation techniques would not be necessary ever again. It has to be remembered that $1 \mathrm{~cm}^{3}$ of soil has more than 3000 species of microorganisms and more than $1 \times 10^{7}$ organism cells. Soil organisms are very important for environmental balance and one of the key issues for shaping a sustainable future is the preservation of biodiversity for maintaining the global natural balance. Until now, there is no information regarding the effect of nanotechnologies on global biodiversity, but there are several attempts to put the nanoscience and the nanotechnology as some of the best humanity advances in recent years. Will some nanotechnologies be our pitfall by ourselves?

\section{How do Patents Increase the Use of Anthropogenic Nanosized Materials in Environmental Remediation?}

\section{Who is Patenting New Nanotechnologies to Improve Environmental Quality?}

According to the Derwent Innovations Index from Web of Science (by restricting the search field topic

Table 1. Authors, institutions, or people to whom patents were assigned, plus patent numbers and reference.

\begin{tabular}{|c|c|}
\hline Author; Institution & Patent numbers; Reference \\
\hline $\begin{array}{c}\text { Zhang, C.; Yantai Inst } \\
\text { Coastal Zone } \\
\text { Res Sustainable }\end{array}$ & $\begin{array}{l}\text { CN106475052-A; [176] } \\
\text { CN105950155-A; [177] } \\
\text { CN105950180-A; [178] } \\
\text { CN105950181-A; [179] }\end{array}$ \\
\hline Yang, Z.; Univ. Cent. South & $\begin{array}{l}\text { CN105733593-A; [180] } \\
\text { CN105733588-A; [181] } \\
\text { CN105647539-A; [182] } \\
\text { CN105598158-A; [183] }\end{array}$ \\
\hline Li, J.; Liu, X. & $\begin{array}{l}\text { CN104801540-A; [184] } \\
\text { CN104807762-A; [185] } \\
\text { CN104801534-A; [186] }\end{array}$ \\
\hline $\begin{array}{l}\text { Cheng, G.; Jiangsu Gaiya En- } \\
\text { vironmental Eng. Co. LTD. }\end{array}$ & $\begin{array}{l}\text { CN105505397-A; [187] } \\
\text { CN105505398-A; [188] } \\
\text { CN105441082-A; [189[ }\end{array}$ \\
\hline $\begin{array}{l}\text { Fang, Z.; Univ South China } \\
\text { Normal }\end{array}$ & $\begin{array}{l}\text { CN105131960-A; [190] } \\
\text { CN105013811-A; [191] } \\
\text { CN103157810-A; [192] }\end{array}$ \\
\hline $\begin{array}{c}\text { Feng, X.; Gefeng } \\
\text { Environmental Protection } \\
\text { Technolo }\end{array}$ & $\begin{array}{l}\text { CN106430598-A; [193] } \\
\text { CN206051687-U; [194] }\end{array}$ \\
\hline $\begin{array}{c}\text { Bezbaruah, A.; Ndsu Res } \\
\text { Found. }\end{array}$ & $\begin{array}{l}\text { WO2014168728-A1; [195] } \\
\text { WO2013173734-A1; [196] }\end{array}$ \\
\hline $\begin{array}{l}\text { Chen, M.; Inst Mineral } \\
\text { Resource Chinese Acad } \\
\text { Geolo }\end{array}$ & $\begin{array}{l}\text { CN104893732-A; [197] } \\
\text { CN104129841-A; [198] }\end{array}$ \\
\hline
\end{tabular}


to 'nano*' and 'remed*'), during the last five years 154 patents have been assigned regarding the topic of nanoscience, nanotechnology, and remediation. After that, we did a manual analysis to set the relevant patents that met the established search topic.

During the last five years only eight authors have published two patents or more regarding nanotechnology, nanoscience, and remediation of soil or water (Table 1).

\section{Main Benefits of Patents Regarding the New Nanotechnologies to Improve Environmental Quality}

In recent years, scientists and technologists have gone further to create new devices or tools in order to improve environmental and human health. Some patents improved other technologies throughout the synthesis of new nanomaterials in order to remediate the environment and save energy [176]. Additionally, we have built a soil-conditioning agent for remediating soil contaminated by heavy metal and reuse the conditioning agent at low cost [177]. Another patent argues that lime powder, hydroxyapatite, nano-silica, gravel, activated carbon, and calcium peroxide can permanently remove heavy metals in the soil, and reduce the toxicity and the leaching concentration of heavy metals in soils by a straightforward and rapid industrial process [178]. Nanocomposites of attapulgite are a repairing agent used in ecological restoration projects in mining areas, and soil remediation projects in agricultural land polluted with heavy metals. These nanocomposites have a particular advantage that quickly and efficiently stabilizes the soil, while they are environmentally friendly [179].

Some bioremediation techniques have also seen patents in order to restore heavy metal- polluted soils. Chai et al. [180] patented a microbial assembly synthesis method for preparing an arsenic-contaminated soil remediation fixing agent. The method enables the preparation of an arsenic-contaminated soil remediation fixing agent with an environmentally friendly process. It does not produce secondary pollution, does not disrupt the physical and chemical properties of the soil, and is non-toxic [181]. Additionally, a method for preparing phosphorus-based bio-carbon material for remediating cadmium-contaminated soil utilizing culture medium of filamentous fungus was also patented [182, 183].

In addition, a remediation method of a contaminated site involves the coating surface of zero-valent nano iron with organic polymer layer. This technology injects the coated zero-valent nano iron into contaminated soil through an injection well, oxidizing zero-valent nano iron and injecting reducing bacterium solution into the contaminated soil, while the growth of indigenous microorganisms and the degradation of pollutants are accelerated [184, 185]. A similar patent was assigned in which a method for degrading organic pollutants of persulfate in water is described [177]. This method enables a high remediation rate of organically polluted water, with strong free-base oxidation ability and a stable reaction system at wide $\mathrm{pH}$ range.

A new technology to remove a contaminant from an aqueous medium required bare nanoscale zero-valent iron (NZVI) particles or calcium $(\mathrm{Ca})$-alginate entrapped NZVI under conditions and for a time effective to sorb the contaminant [195]. According to the inventor, phosphate, selenium, and other collected nutrients can be recycled as an agricultural fertilizer. The method is a green technology that follows the principles of reduce, reuse, and recycle [195]. Additionally, a new functionalized amphiphilic plant-based copolymer was patented. It was stated that the copolymer facilitates improved dispersion and suspension of iron nanoparticles (FeNPs) in water for application in groundwater remediation [196]. Furthermore, the copolymers are surface active due to their amphiphilic nature. Thus, the compounds may provide an additional advantage, i.e., antimicrobial activity.

Another patent has described the synthesis of a magnetic nanomaterial with a core made of a magnetic material while an organic matter cladding layer is provided outside the core. This magnetic nanomaterial is used to remediate heavy metal-contaminated soil [186].

A method for preparing iron-based bio-char material used for remediation of arsenic-polluted soil was also patented [181]. The method enables preparation of ironbased bio-char material with a simple process and at low cost [181].

Some mixtures of nanomaterials have also been patented. For example, a mixture of nano-material containing bentonite, fly ash, magnesium nitrate, barium oxide nanoparticles, polymeric ferric aluminum silicate, stachydrine, dimethylol urea calcium aluminate, magnesium aluminosilicate, and phospholipid was patented in 2015 in order to remediate soils polluted with lead or copper ion [187-189]. Another mixture was patented as a remediating agent for heavy metal lead-cadmium and lead-cadmium sulfide compositecontaminated soil [197]. This remediating agent contains 5-20 parts mass modified carbon nanotubes, 10-60 parts mass modified clay mineral, and 10-75 parts mass lime. According to the inventors, the remediating agent can be prepared in a simple and economical manner, and reduces $75-90 \%$ cadmium [197].

The preparation of composite material used for insitu remediation of lead-contaminated soil has also been patented [190]. According to the authors, the method provides soil-remediation composite material having high soil repairing efficiency. Additionally, the same authors patented a method for preparing biochar particles used in preparing load-type zero-value nanoiron particles for in-situ remediation of chromiumcontaminated soil [191]. Additionally, a method for preparing dispersed nanometer nickel/iron bimetallic particles that are utilized for in-situ remediation of poly brominated diphenyl ethers was also patented [192].

In addition to the nanomaterials, other devices also have been patented in order to remediate soil or 
water. An ecological bag filled with multifunctional nanocomposite material was patented to remove heavy metals, total nitrogen, and phosphorus from soil or water [193, 194]. However, this device cannot be found in the market yet.

In general, the patents described above represent a sustainable practice that facilitates efficient recovery of heavy metals or wasted nutrients, and the dissipation of pollutants (at least this is the genuine intention of the inventors). The inventors argue that these technologies are well suited to the needs of the fertilizer industry, municipalities, and pollution control agencies. In this way, for example, when used as fertilizer, NZVI or Caalginate-entrapped NZVI supply not only the adsorbed nutrient (e.g., phosphate or selenium), but also iron. In addition, the release of nutrients (e.g., phosphate, selenium, and iron) takes place over time, thus providing a time-release action. Therefore, if everything goes according to the inventors' plans, the nutrients are supplied in a bioavailable form and can be efficiently taken up by plants and microorganisms during the vegetative or reproductive growth.

Several patents have been reported arguing for the environmentally friendly synthesis of new nanomaterials with specific and worthy properties in order to dissipate pollutants and/or remediate contaminated sites. However, additional research regarding the ecological effect of using these modern nanomaterials for several years has to be done. Otherwise, these patents might jeopardize the sustainability which is widely sought by scientists, technologists, politicians, and common people worldwide.

\section{Conclusions}

Nanotechnologies and nanosciences have been very useful for delivering some materials, products, or services with better characteristics compared to their respective bulk material. Also, these areas have also provided some nanosized materials to the environment, and the human and environmental concerns have been raised. However, nanotechnologies have also been used to dissipate soil pollution, but benefits and risks have been discussed recently. It is well known that some strategies to remediate polluted soils through nanotechnology might be accomplished, but some questions have to be answered prior the spread of nanoremediation, i.e., nanoparticle toxicity has to be assessed while the standardization of techniques should be set by scientists and decision-makers worldwide. The cutting-edge knowledge regarding the use of nanoparticles to decontaminate soils has to move forward, but environmental quality, human health, and social welfare should also be ensured. Otherwise, these patents regarding modern nanomaterials might jeopardize sustainability.

\section{Acknowledgements}

This research was founded by 'Ciencia Básica SEP-CONACyT' projects 151881 and 287225, the Sustainability of Natural Resources and Energy Program (Cinvestav-Saltillo), and Cinvestav Zacatenco. G.M-P received grant-aided support from Becas Conacyt. F.F-L, E.V-N, F.L-V, J.P-M, and A.M-N received grantaided support from Sistema Nacional de Investigadores (SNI), México.

\section{Conflict of Interest}

The authors declare no conflict of interest.

\section{References}

1. SEVIK H., CETIN M. Effects of water stress on seed germination for select landscape plants. Pol. J. Enviro. Stud. 24 (2), 689, 2015.

2. CETIN M. Sustainability of urban coastal area management: A case study on Cide, J. Sustain. Forest. 35 (7), 527, 2016.

3. CETIN M. Landscape Engineering, Protecting Soil, and Runoff Storm Water, In: Advances in Landscape Architecture-Environmental Sciences, OZYAVUZ M. (Ed.). InTech, 697-722, 2013.

4. YIGIT N., SEVIK H., CETIN M., GUL L. Clonal variation in chemical wood characteristics in Hanönü (Kastamonu) Günlüburun black pine (Pinus nigra Arnold. subsp. pallasiana (Lamb.) Holmboe) seed orchard. J. Sustain. Forest. 35 (7), 515, 2016.

5. YIGIT N., SEVIK H., CETIN M., KAYA N. Determination of the effect of drought stress on the seed germination in some plant species. In: Water stress in plants, Eds: ISMAIL M.D., MOFIZUR R., ZINNAT A. B., HIROSHI H. (Eds), Intech Open, 43-62. 2016.

6. GUNEY K., CETIN M., SEVIK H., GUNEY K.B. Influence of germination percentage and morphological properties of some hormones practice on Lilium martagon L. seeds. Oxid. Comm. 39 (1-II), 466, 2016.

7. CETIN M., SEVIK H. Measuring the impact of selected plants on indoor $\mathrm{CO}_{2}$ concentrations. Pol. J. Enviro. Stud. 25 (3), 973, 2016.

8. GUNEY K., CETIN M., GUNEY K.B. MELEKOGLU A. The effects of some hormone applications on Lilium martagon L. germination and morpholgical characters. Pol. J. Enviro. Stud. 26 (6), 2533, 2017.

9. CETIN M., SEVIK H., SAAT A. Indoor air quality: the samples of safranbolu bulak Mencilis cave. Fresenius Environ. Bull. 26(10): 5965, 2017.

10. SEVIK H., CETIN M., KAPUCU, O. Effect of light on young structures of turkish fir (Abies nordmanniana subsp. bornmulleriana). Oxid. Comm. 39 (1-II), 485, 2016.

11. SEVIK H., AHMAIDA E.A., CETIN M. Change of the air quality in the urban open and green spaces: kastamonu sample. In: Ecology, planning and design. Eds: KOLEVA I., ULKU D.Y., LAHCEN B. (Eds.) University Press, 409422, 2017. 
12. RABOT E., WIESMEIER M., SCHLUTER S., VOGEL H.J. Soil structure as an indicator of soil functions: A review. Geoderma. 314, 122, 2018.

13. LI G., SUN G.X., REN Y., LUO X.S., ZHU Y.G. Urban soil and human health: a review. Eur. J. Soil Sci. 69 (1), 196, 2018.

14. ABDALLA M., HASTING A., CHADWICK D.R., JONES D.L., EVANS C.D., JONES M.B., REES R.M., SMITH P. Critical review of the impacts of grazing intensity on soil organic carbon storage and other soil quality indicators in extensively managed grasslands. Agric. Ecosyst. Environ. 253, 62, 2018.

15. BIZO M.L., LEVEI E.A., KOTHE E., SENILA M., MODOI C.O., OZUNU A. Chemical assessment of soil quality for ecological remediation strategies. Carpath. J. Earth Environ. Sci. 10 (4), 195, 2015.

16. DOUCETTE W.J., SHUNTHIRASINGHAM C., DETTENMAIER E.M., ZALESKI R.T., FANTKE P., ARNOT J.A. A review of measured bioaccumulation data on terrestrial plants for organic chemicals: metrics, variability, and the need for standardized measurement protocols. Environ. Toxicol. Chem. 37 (1), 21, 2018.

17. DAS P., BARUA S., SARKAR S., KARAK N., BHATTACHAYYA P., RAZA N., KIM K.H., BHATTACHARYA S.S. Plant extract-mediated green silver nanoparticles: Efficacy as soil conditioner and plant growth promoter. J. Hazard. Matter. 346, 62, 2018.

18. LU S.G., ZHANG X., XUE Y.F. Application of calcium peroxide in water and soil treatment: A review. J. Hazard. Matter. 337, 163, 2017.

19. GOUDA S., KERRY R.G., DAS G., PARAMITHIOTIS S., SHIN H.S., PATRA J.K. Revitalization of plant growth promoting rhizobacteria for sustainable development in agriculture. Microbiol. Res. 206, 131, 2018.

20. LEON-SILVA S., FERNÁNDEZ-LUQUEÑO F., LOPEZ-VALDEZ F. Silver nanoparticles (AgNP) in the environment: a review of potential risks on human and environmental health. Water Air Soil Poll. 227, Article number 306, 2016.

21. VANCE M.E., KUIKEN T., VEJERANO E.P., MCGINNIS S.P., HOCHELLA M.F., REJESKI D., HULL M.S. Nanotechnology in the real world: Redeveloping the nanomaterial consumer products inventory. Beilstein $\mathrm{J}$. Nanotechnol. 6, 1769, 2015.

22. FERNÁNDEZ-LUQUEÑO F., LÓPEZ-VALDEZ F., VALERIO-RODRÍGUEZ M.F., PARIONA N., HERNÁNDEZ-LÓPEZ J.L., GARCÍA-ORTÍZ I., LÓPEZBALTAZAR J., VEGA-SÁNCHEZ M.C., ESPINOZAZAPATA R., ACOSTA-GALLEGOS J.A. In: Fertilizers: Components, uses in agriculture and environmental impacts; LÓPEZ-VALDEZ F., FERNÁNDEZ-LUQUEÑO F. Eds.; Nova. USA. 211, 2014.

23. FERNÁNDEZ-LUQUEÑO F., LOPEZ-VALDEZ F., DENDOOVEN L., LUNA-SUAREZ S., CEBALLOSRAMIREZ J.M. Why wastewater sludge stimulates and accelerates removal of PAHs in polluted soils? Appl. Soil Ecol. 101, 1, 2016.

24. FERNÁNDEZ-LUQUEÑO F., LOPEZ-VALDEZ F., SARABIA-CASTILLO C.R., GARCÍA-MAYAGOITIA S., PEREZ-RIOS S.R. Bioremediation of polycyclic aromatic hydrocarbons-polluted soils at laboratory and field scale: a review of the literature on plants and microorganisms. In: Enhancing cleanup of environmental pollutants Vol. 1: Biological approaches, ANJUM N.A., GILL S.S., TUTEJA N. (Eds.), Springer. Switzerland, 43, 2017.
25. FERNÁNDEZ-LUQUEÑO F., LOPEZ-VALDEZ F., PÉREZ-MORALES C., GARCÍA-MAYAGOITIA S., SARABIA-CASTILLO C.R., PEREZ-RIOS S.R. Enhancing decontamination of PAHs-polluted soils: role of organic and mineral amendments. In: Enhancing cleanup of environmental pollutants Vol. 2: Non-biological approaches, ANJUM N.A., GILL S.S., TUTEJA N. (Eds.), Springer. Switzerland, 339, 2017.

26. GILLIES G., MACKENZIE K., KOPINKE F.D., GEORGI A. Fluorescence labelling as tool for zeolite PARTICLE tracking in nanoremediation approaches. Sci. Total Environ. 550, 820, 2016.

27. GIL-DIAZ M., DIEZ-PASCUAL S., GONZALEZ A., ALONSO J., RODRIGUEZ-VALDEZ E., GALLEGO J.R., LOBO M.C. A nanoremediation strategy for the recovery of an As-polluted soil. Chemosphere. 149, 137, 2016.

28. SCHIVVY A., MAES H.M., KOSKE D., FLECKEN M., SCHMIDT K.R., SCHELL H., TIEHM A., KAMPTNER A., THUMMLER S., STANJEK H., HEGGEN M., DUNIN-BORKOWSKI R.E., BRAUN J.M., SCHAFFER A., HOLLERT H. The ecotoxic potential of a new zerovalent iron nanomaterial, designed for the elimination of halogenated pollutants, and its effect on reductive dechlorinating microbial communities. Environ. Pollut. 216, 419, 2016

29. NATHANAIL C.P., GILLETT A., MCCAFFREY C., NATHANAIL J., OGDEN R. A preliminary risk assessment protocol for renegade nanoparticles deployed during nanoremediation. Remed. J. 26, 95, 2016.

30. THENG B.K., YUAN G. Nanoparticles in the soil environment. Elements, 4, 395, 2008.

31. XU C., PENG C., SUN L., ZHANG S., HUANG H., CHEN Y., SHI J. Distinctive effects of $\mathrm{TiO}_{2}$ and $\mathrm{CuO}$ nanoparticles on soil microbes and their community structures in flooded paddy soil. Soil Biol. \& Biochem. 86, 24, 2015.

32. HE S., FENG Y., NI J., SUN Y., XUE L., FENG Y., YU Y., LIN X., YANG L. Different responses of soil microbial metabolic activity to silver and iron oxide nanoparticles. Chemosphere, 147, 195, 2016.

33. BAWA R., BAWA S.R., MAEBIUS S.B., FLYNN T., WEI C. Protecting new ideas and inventions in nanomedicine with patents. Nanomed-Nanotechnol, 1, 150, 2005.

34. KELLER A.A., MCFERRAN S., LAZAREVA A., SUH S. Global life cycle releases of engineered nanomaterials. J. Nanopart. Res., 15, 1, 2013.

35. PARISI C., VIGANI M., RODRÍGUEZ-CEREZO E. Agricultural Nanotechnologies: What are the current possibilities? Nano Today, 10, 124, 2015.

36. FAO/WHO. State of the Art on the Initiatives and Activities Relevant to Risk Assessment and Risk Management of Nanotechnologies in the Food and Agriculture Sectors. Technical Paper, FAO and WHO, Rome. 2013. Available online at: http://www.fao.org/docrep/018/i3281e/i3281e.pdf (Accessed May 8, 2017)

37. ARAGAY G., PINO F., MERKOCI A. Nanomaterials for sensing and destroying pesticides. Chem. Rev. 112, 5317, 2012.

38. YAO J., YANG M., DUAN Y. Chemistry, biology, and medicine of fluorescent nanomaterials and related systems: new insights into biosensing, bioimaging, genomics, diagnostics, and therapy. Chem. Rev. 114, 6130, 2014.

39. CHEN H., YADA R. Nanotechnologies in agriculture: New tools for sustainable development. Trends Food Sci. Tech. 22, 585, 2011. 
40. CORRADINI E., DE MOURA M.R., MATTOSO L.H.C. A preliminary study of the incorparation of NPK fertilizer into chitosan nanoparticles. Express Polym. Lett. 4, 509, 2010.

41. DEROSA M.C., MONREAL C., SCHNITZER M., WALSH R., SULTAN Y. Nanotechnology in fertilizers. Nat. Nanotechnol. 5, 91, 2010.

42. GRILLO R., DE MELO N.F., DE LIMA R., LOURENÇO R.W., ROSA A.H., FRACETO L.F. Characterization of atrazine-loaded biodegradable poly (hydroxybutyrate-cohydroxyvalerate) microspheres. J. Polym. Environ. 18, 26, 2010.

43. GRILLO R., DOS SANTOS N.Z.P., MARUYAMA C.R., ROSA A.H., DE LIMA R., FRACETO L.F. Poly ( $\varepsilon$-caprolactone) nanocapsules as carrier systems for herbicides: Physico-chemical characterization and genotoxicity evaluation. J. Hazard. Mater. 231, 1, 2012.

44. GOLDWASSER Y., EIZENBERG H., GOLAN S., KLEIFELD Y. Control of Orobanche crenata and Orobanche aegyptiaca in parsley. Crop Prot. 22, 295, 2003.

45. MISHRA S., SINGH H.B. Biosynthesized silver nanoparticles as a nanoweapon against phytopathogens: exploring their scope and potential in agriculture. Appl. Microbiol. Biotechnol. 99, 1097, 2015.

46. NURUZZAMAN M., RAHMAN M.M., LIU Y., NAIDU R. Nanoencapsulation, nano-guard for pesticides: a new window for safe application. J. Agric. Food Chem. 64, 1447, 2016.

47. PETEU S.F., OANCEA F., SICUIA O.A., CONSTANTINESCU F., DINU S. Responsive polymers for crop protection. Polymers, 2, 229, 2010.

48. MUKHOPADHYAY S.S. Nanotechnology in agriculture: prospects and constraints. Nanotechnol. Sci. Appl. 7, 63, 2014.

49. DASGUPTA N., RANJAN S., MUNDEKKAD D., RAMALINGAM C., SHANKER R., KUMAR A. Nanotechnology in agro-food: from field to plate. Food Res. Int. 69, 381, 2015.

50. JOHNSTON C.T. Probing the nanoscale architecture of clay minerals. Clay Miner. 45, 245, 2010.

51. BIN HUSSEIN M.Z., ZAINAL Z., YAHAYA A.H., FOO D.W.V. Controlled release of a plant growth regulator, $\alpha$-naphthaleneacetate from the lamella of $\mathrm{Zn}$-Al-layered double hydroxide nanocomposite. J. Control Release. 82, 417, 2002.

52. KOTTEGODA N., MUNAWEERA I., MADUSANKA N., KARUNARATNE V. A green slow-release fertilizer composition based on urea-modified hydroxyapatite nanoparticles encapsulated wood. Curr. Sci. 101, 73, 2011.

53. JINGHUA G. Synchrotron radiation, soft-X-ray spectroscopy and nanomaterials. Int. J. Nanotechnol. 1, 193, 2004.

54. ZHANG F., WAN R., XIAO Q., WANG Y., ZHANG J. Effects of slow/controlled-release fertilizer cemented and coated by nano-materials on biology. II. Effects of slow/ controlled-release fertilizer cemented and coated by nanomaterials on plants. Nanoscience, 11, 18, 2006.

55. EL SALMAWI K.M. Application of polyvinyl alcohol (PVA)/carboxymethyl cellulose (CMC) hydrogel produced by conventional crosslinking or by freezing and thawing. J. Macromol. Sci. A. 44, 619, 2007.

56. SEKHON B.S. Nanotechnology in agri-food production: an overview. Nanotechnol. Sci. Appl. 7, Article number 31, 2014.
57. JATAV G.K., MUKHOPADHYAY R. Characterization of swelling behavior of anoclay composite. Int. J. Innov. Res. Sci. Eng. Technol. 2, 1560, 2013.

58. MAHFOUDHI N., BOUFI S. Poly (acrylic acidco-acrylamide)/cellulose nanofibrils nanocomposite hydrogels: effects of CNFs content on the hydrogel properties. Cellulose, 23, 3691, 2016.

59. KOTTEGODA N., MUNAWEERA I., SAMARANAYAKE L., GUNASEKARA S., DE ALWIS A., KARUNARATNE V., MADUSANKA A.N. U.S. Patent No. 8,617,284. Washington, DC: U.S. Patent and Trademark Office. 2013.

60. LIU R., LAL R. Potentials of engineered nanoparticles as fertilizers for increasing agronomic productions. Sci. Total Environ. 514, 131, 2015.

61. LI Z.Z., CHEN J.F., LIU F., LIU A.Q., WANG Q., SUN H.Y., WEN L.X. Study of UV-shielding properties of novel porous hollow silica nanoparticle carriers for avermectin. Pest Manag. Sci. 63, 241, 2007.

62. KHOT L.R., SANKARAN S., MAJA J.M., EHSANI R., SCHUSTER E.W. Applications of nanomaterials in agricultural production and crop protection: a review. Crop Prot. 35, 64, 2012.

63. ZHAO R., TORLEY P., HALLEY P.J. Emerging biodegradable materials: starch-and protein-based bionanocomposites. J. Mater. Sci. 43, 3058, 2008.

64. LEHMANN J., JOSEPH S. Biochar for environmental management: Science, technology, and implementation. London. Taylor \& Francis. New York, 2015.

65. PETERSON S.C., JACKSON M.A., APPELL M. Advances in applied nanotechnology for agriculture Park B. and Appell. Med. Washington, DC: American Chemical Society. 2013.

66. ARAGAY G., PONS J., ROS J., MERKOÇI A. Aminopyrazole-based ligand induces gold nanoparticle formation and remains available for heavy metal ions sensing. A simple "mix and detect" approach. Langmuir, 26, 10165, 2010.

67. KREYLING W.G., SEMMLER-BEHNKE M., CHAUDHRY Q. A complementary definition of nanomaterial. Nano Today, 5, 165, 2010.

68. ARIVALAGAN K., RAVICHANDRAN S., RANGASAMY K., KARTHIKEYAN E. Nanomaterials and its potential applications. Int. J. Chem. Tech. Res. 3, 534, 2011.

69. AIKEN G.R., HSU-KIM H., RYAN J.N. Influence of dissolved organic matter on the environmental fate of metals, nanoparticles, and colloids. Environ. Sci Technol. 45, 3196, 2011.

70. PETERSEN E.J., ZHANG L., MATTISON N.T., O'CARROLL D.M., WHELTON A.J., UDDIN N., CHEN K.L. Potential release pathways, environmental fate, and ecological risks of carbon nanotubes. Environ. Sci. Technol. 45, 9837, 2011.

71. MURR L.E., GARZA K.M., SOTO K.F., CARRASCO A., POWELL T.G., RAMIREZ D.A., VENZOR J. Cytotoxicity assessment of some carbon nanotubes and related carbon nanoparticle aggregates and the implications for anthropogenic carbon nanotube aggregates in the environment. Int. J. Environ. Res. Public Health. 2, 31, 2005.

72. ZOSKY G.R., BOYLEN C.E., WONG R.S., SMIRK M.N., GUTIÉRREZ L., WOODWARD R.C., COOK A. Variability and consistency in lung inflammatory responses to particles with a geogenic origin. Respirology, 19, 58, 2014. 
73. RIBEIRO J., FLORES D., WARD C.R., SILVA L.F. Identification of nanominerals and nanoparticles in burning coal waste piles from Portugal. Sci. Total Environ. 408, 6032, 2010.

74. KUMAR P., PIRJOLA L., KETZEL M., HARRISON R.M. Nanoparticle emissions from 11 non-vehicle exhaust sources - A review. Atmos. Environ. 67, 252, 2013.

75. NGUYEN P.K., LEE K.H., MOON J., KIM S.I., AHN K.A., CHEN L.H., BERKOWITZ A.E. Spark erosion: a high production rate method for producing Bi0. $5 \mathrm{Sbl}$. 5Te3 nanoparticles with enhanced thermoelectric performance. Nanotechnology, 23, Article number 415604, 2012.

76. US-EPA. Nanotechnology and Nanomaterials Research. Available on line at: www.epa.gov/nanoscience/ (Accessed October 30, 2016). 2012.

77. BRAR S.K., VERMA M., TYAGI R.D., SURAMPALLI R.Y. Engineered nanoparticles in wastewater and wastewater sludge--evidence and impacts. Waste Manag. 30, 504, 2010.

78. MUELLER N.C., NOWACK B. Exposure modeling of engineered nanoparticles in the environment. Environ. Sci. Technol. 42, 4447, 2008.

79. NOWACK B., MUELLER N.C., KRUG H.F., WICK $\mathrm{P}$. How to consider engineered nanomaterials in major accident regulations? Env. Sci. Eur. 26, 1, 2014.

80. ELSAESSER A., HOWARD C.V. Toxicology of nanoparticles. Adv. Drug Deliv. Rev. 64, 129, 2012.

81. BISWAS P., WU C.Y. Nanoparticles and the environment. J. Air Waste Manage Assoc. 55, 708, 2005.

82. AHAMED M., ALSALHI M.S., SIDDIQUI M.K.J. Silver nanoparticle applications and human health. Clin. Chim. Acta, 411, 1841, 2010.

83. LUNGU M., NECULAE A., BUNOIU M., BIRIS C. Nanoparticles' Promises and Risks. Ed Springer International Publishing Switzerland. 2015.

84. HOCHELLA M.F., LOWER S.K., MAURICE P.A., PENN R.L., SAHAI N., SPARKS D.L., TWINING B.S. Nanominerals, mineral nanoparticles, and earth systems. Science, 319, 1631, 2008.

85. DOMINGOS R.F., TUFENKJI N., WILKINSON K.J. Aggregation of titanium dioxide nanoparticles: role of a fulvic acid. Environ. Sci. Technol. 43, 1282, 2009.

86. SIX J., BOSSUYT H., DEGRYZE S., DENEF K. A history of research on the link between (micro) aggregates, soil biota, and soil organic matter dynamics. Soil Tillage Res. 79, 7, 2004

87. WU C.Y., ZHUANG L., ZHOU S.G., YUAN Y., YUAN T., LI F.B. Humic substance-mediated reduction of iron (III) oxides and degradation of 2, 4-D by an alkaliphilic bacterium, Corynebacterium humireducens MFC-5. Microb. Biotechnol. 6, 141, 2013.

88. SENESI N. Binding mechanisms of pesticides to soil humic substances. Sci. Total Environ. 123, 63, 1992.

89. DE MORAIS J.L., ZAMORA P.P. Use of advanced oxidation processes to improve the biodegradability of mature landfill leachates. J. Hazard. Mater. 123, 181, 2005.

90. GUERARD J.J., MILLER P.L., TROUTS T.D., CHIN Y.P. The role of fulvic acid composition in the photosensitized degradation of aquatic contaminants. Aquat. Sci. 71, 160, 2009.

91. NAVARRO E., BAUN A., BEHRA R., HARTMANN N.B., FILSER J., MIAO A.J., SIGG L. Environmental behavior and ecotoxicity of engineered nanoparticles to algae, plants, and fungi. Ecotoxicology, 17, 372, 2008.
92. SHI Z., SHAO L., JONES T.P., LU S. Microscopy and mineralogy of airborne particles collected during severe dust storm episodes in Beijing, China. J. Geophys. Res. Atmos. 110, Article number D01303. 2005.

93. BAKSHI S., HE Z.L., HARRIS W.G. Natural nanoparticles: implications for environment and human health. Crit. Rev. Env. Sci. Technol. 45, 861, 2015.

94. MOHARRER S., MOHAMMADI B. GHARAMOHAMMADI R.A., YARGOLI M. Biological synthesis of silver nanoparticles by Aspergillus flavus, isolated from soil of Ahar copper mine. Indian J. Sci. Technol. 5, 2443, 2012.

95. GLOVER R.D., MILLER J.M., HUTCHISON J.E. Generation of metal nanoparticles from silver and copper objects: nanoparticle dynamics on surfaces and potential sources of nanoparticles in the environment. ACS Nano, 5, 8950, 2011.

96. GE Y., SCHIMEL J.P., HOLDEN P.A. Evidence for negative effects of $\mathrm{TiO}_{2}$ and $\mathrm{ZnO}$ nanoparticles on soil bacterial communities. Environ. Sci. Technol. 45, 1659, 2011.

97. KOKURA S., HANDA O., TAKAGI T., ISHIKAWA T., NAITO Y., YOSHIKAWA T. Silver nanoparticles as a safe preservative for use in cosmetics. Nanomed-Nanotechnol. 6, 570, 2010

98. STEVENS P.D., LI G., FAN J., YEN M., GAO Y. Recycling of homogeneous Pd catalysts using superparamagnetic nanoparticles as novel soluble supports for Suzuki, Heck, and Sonogashira cross-coupling reactions. Chem. Commun. 35, 4435, 2005.

99. PANKHURST Q.A., CONNOLLY J., JONES S.K., DOBSON J.J. Applications of magnetic nanoparticles in biomedicine. J. Phys. D. Appl. Phys. 36, Article number R167, 2003.

100.CHO K., WANG X.U., NIE S., SHIN D.M. Therapeutic nanoparticles for drug delivery in cancer. Clin. Cancer Res. 14, 1310, 2008.

101. ZHANG M., HE F., ZHAO D., HAO X. Degradation of soil-sorbed trichloroethylene by stabilized zero valent iron nanoparticles: effects of sorption, surfactants, and natural organic matter. Water Res. 45, 2401, 2011.

102.DANKOVICH T.A., GRAY D.G. Bactericidal paper impregnated with silver nanoparticles for point-of-use water treatment. Environ. Sci. Technol. 45, 1992, 2011.

103. GUO K., LI Y., YANG J., ZOU Z., XUE X., LI $\mathrm{X}$, YANG H. Nanosized $\mathrm{Mn}-\mathrm{Ru}$ binary oxides as effective bifunctional cathode electrocatalysts for rechargeable $\mathrm{Li}_{-} \mathrm{O}_{2}$ batteries. J. Mater. Chem. A. 2, 1509, 2014.

104.GUO J. Synchrotron radiation, soft-X-ray spectroscopy and nanomaterials. Int. J. Nanotechnol. 1, 193, 2004.

105.CHATTERJEE R. The challenge of regulating nanomaterials. Environ. Sci. Technol. 42, 339, 2008.

106. RAI M., YADAV A., GADE A. Silver nanoparticles as a new generation of antimicrobials. Biotechnol. Adv. 27, 76, 2009.

107. JU-NAM Y., LEAD J.R. Manufactured nanoparticles: an overview of their chemistry, interactions and potential environmental implications. Sci. Total Environ. 400, 396, 2008.

108.BOWMAN D.M., HODGE G.A. A small matter of regulation: an international review of nanotechnology regulation. Columbia Sci. Technol. Law Rev. 8, Article number 1, 2007.

109. MAYNARD A.D., AITKEN R.J., BUTZ T., COLVIN V., DONALDSON K., OBERDÖRSTER G., TINKLE 
S.S. Safe handling of nanotechnology. Nature, 444, 267, 2006.

110. KANNAN S., GARIEPY Y., RAGHAVAN V. Optimization of enzyme hydrolysis of seafood waste for microwave hydrothermal. Energy Fuels, 29, 8006, 2015.

111. BERUBE D.M., SEARSON E.M., MORTON T.S., CUMMINGS C.L. Project on emerging nanotechnologies. Consumer product inventory evaluated. Nanotech, Law \& Business, 7, 152, 2010.

112. SOM C., BERGES M., CHAUDHRY Q., DUSINSKA M., FERNANDES T.F., OLSEN S.I., NOWACK B. The importance of life cycle concepts for the development of safe nanoproducts. Toxicology, 269, 160, 2010.

113. HISCHIER R., WALSER T. Life cycle assessment of engineered nanomaterials: state of the art and strategies to overcome existing gaps. Sci Total Environ. 425, 271, 2012.

114. MACHADO S., PINTO S.L., GROSSO J.P., NOUWS H.P.A., ALBERGARIA J.T., DELERUE-MATOS C. Green production of zero-valent iron nanoparticles using tree leaf extracts. Sci. Total Environ. 445, 1, 2013.

115. KARN B., KUIKEN T., OTTO M. Nanotechnology and insitu remediation: a review of the benefits and potential risks. Ciência \& Saúde Coletiva, 16, 165, 2011.

116. ROEHL K.E., MEGGYES T., SIMON F.G., STEWART D.I. Behaviour of uranium in elemental iron and hydroxyapatite reactive barriers: column experiments. Eds. Elsevier. New York. 2005.

117. SHIH Y.H., TAI Y.T. Reaction of decabrominated diphenyl ether by zerovalent iron nanoparticles. Chemosphere, 78, 1200, 2010.

118. ZHU B.W., LIM T.T., FENG J. Reductive dechlorination of 1, 2, 4-trichlorobenzene with palladized nanoscale $\mathrm{Fe} 0$ particles supported on chitosan and silica. Chemosphere, 65, 1137, 2006.

119. LIANG F., FAN J., GUO Y., FAN M., WANG J., YANG $\mathrm{H}$. Reduction of nitrite by ultrasound-dispersed nanoscale zero-valent iron particles. Ind. Eng. Chem. Res. 47, 8550, 2008.

120.GIASUDDIN A.B., KANEL S.R., CHOI H. Adsorption of humic acid onto nanoscale zerovalent iron and its effect on arsenic removal. Environ. Sci. Technol. 41, 2022, 2007.

121. ELLIOTT D.W., LIEN H.L., ZHANG W.X. Degradation of lindane by zero-valent iron nanoparticles. J. Environ. Eng. 135, 317, 2009.

122.SHU H.Y., CHANG M.C., YU H.H., CHEN W.H. Reduction of an azo dye Acid Black 24 solution using synthesized nanoscale zerovalent iron particles. J. Colloid Interface Sci. 314, 89, 2007.

123. MACHADO S., PACHECO J.G., NOUWS H.P.A., ALBERGARIA J.T., DELERUE-MATOS C. Characterization of green zero-valent iron nanoparticles produced with tree leaf extracts. Sci. Total Environ. 533, 76, 2015.

124.SHI L.N., ZHANG X., CHEN Z.L. Removal of chromium (VI) from wastewater using bentonite-supported nanoscale zero-valent iron. Water Res. 45, 886, 2011.

125.TRUJILLO-REYES J., PERALTA-VIDEA J.R., GARDEA-TORRESDEY J.L. Supported and unsupported nanomaterials for water and soil remediation: are they a useful solution for worldwide pollution? J. Hazard Mater. 280, 487, 2014.

126. WANG S., SUN H., ANG H.M., TADÉ M.O. Adsorptive remediation of environmental pollutants using novel graphene-based nanomaterials. Chem. Eng. J. 226, 336, 2013.
127. QIU X., FANG Z., LIANG B., GU F., XU Z. Degradation of decabromodiphenyl ether by nano zero-valent iron immobilized in mesoporous silica microspheres. J. Hazard. Mater. 193, 70, 2011.

128. XIE Y., CHENG W., TSANG P.E., FANG Z. Remediation and phytotoxicity of decabromodiphenyl ether contaminated soil by zero valent iron nanoparticles immobilized in mesoporous silica microspheres. J. Environ. Manag. 166, 478, 2016.

129. SU H., FANG Z., TSANG P.E., ZHENG L., CHENG W., FANG J., ZHAO D. Remediation of hexavalent chromium contaminated soil by biochar-supported zero-valent iron nanoparticles. J. Hazard. Mater. 318, 533, 2016.

130.GONG Y., LIU Y., XIONG Z., KABACK D., ZHAO D. Immobilization of mercury in field soil and sediment using carboxymethyl cellulose stabilized iron sulfide nanoparticles. Nanotechnology, 23, Article number 294007, 2012.

131. OLSON M.R., BLOTEVOGEL J., BORCH T., PETERSEN M.A., ROYER R.A., SALE T.C. Long-term potential of in situ chemical reduction for treatment of polychlorinated biphenyls in soils. Chemosphere, 114, 144, 2014.

132.EL-TEMSAH Y.S., JONER E.J. Effects of nano-sized zero-valent iron (nZVI) on DDT degradation in soil and its toxicity to collembola and ostracods. Chemosphere, 92, 131, 2013.

133.DE VELOSA A.C., NOGUEIRA R.F.P. 2, 4-Dichlorophenoxyacetic acid (2, 4-D) degradation promoted by nanoparticulate zerovalent iron (nZVI) in aerobic suspensions. J. Environ. Manag. 121, 72, 2013.

134.FAN W., PENG R., LI X., REN J., LIU T., WANG X. Effect of titanium dioxide nanoparticles on copper toxicity to Daphnia magna in water: Role of organic matter. Water Res. 105, 129, 2016.

135. SHEN X., ZHAO L., DING Y., LIU B., ZENG H., ZHONG L., LI X. Foam, a promising vehicle to deliver nanoparticles for vadose zone remediation. J. Hazard. Mater. 186, 1773, 2011.

136. KATTI K.V. Renaissance of nuclear medicine through green nanotechnology: functionalized radioactive gold nanoparticles in cancer therapy - my journey from chemistry to saving human lives. J. Radioanal Nucl. Chem. 1, Article number 10, 2016.

137. SHALABY S.M., KHATER M.K., PERUCHO A.M., MOHAMED S.A., HELWA I., LAKNAUR A., ALHENDY A.A. Magnetic nanoparticles as a new approach to improve the efficacy of gene therapy against differentiated human uterine fibroid cells and tumorinitiating stem cells. Fertil Steril. 105, 1638, 2016.

138. SIDDIQUI I.A., SANNA V. Impact of nanotechnology on the delivery of natural products for cancer prevention and therapy. Mol. Nutr. Food Res. 60, 1330, 2016.

139. WANG P., LI Z., MA Y., SUN X., LIU Z., ZHANG J. The coarse-grained model for a water/oil/solid system: based on the correlation of water/air and water/oil contact angles. RSC Adv. 5, 51135, 2015.

140. WU Q., RIDGE C.J., ZHAO S., ZAKHAROV D., CEN J., TONG X., ORLOV A. Development of a new generation of stable, tunable, and catalytically active nanoparticles produced by the helium nanodroplet deposition method. J. Phys. Chem. Lett. 7, 2910, 2016.

141. INCERTI S., BARBERET P., DÉVÈS G., MICHELET C., FRANCIS Z., IVANTCHENKO V., KARAMITROS M. Comparison of experimental proton-induced fluorescence 
spectra for a selection of thin high-Z samples with Geant4 Monte Carlo simulations. Nucl. Instr. Meth. Phys. Res. 358, 210, 2015.

142.LAMBE U., MINAKSHI P., BRAR B., GURAY M., RANJAN K., BANSAL N. TUFARELLI V. Nanodiagnostics: a new frontier for veterinary and medical sciences. J. Exp. Biol. Agric. 4, 307, 2016.

143. RANGNEKAR A., LABEAN T.H. Building DNA nanostructures for molecular computation, templated assembly, and biological applications. Acc. Chem. Res. 47, 1778, 2014

144.SCHMIDT T.L., BELIVEAU B.J., UCA Y.O., THEILMANN M., DA CRUZ F., WU C.T., SHIH W.M. Scalable amplification of strand subsets from chipsynthesized oligonucleotide libraries. Nat Commun. 6, Article number 8634, 2015.

145. DAS S., SEN B., DEBNATH N. Recent trends in nanomaterials applications in environmental monitoring and remediation. Environ. Sci. Pollut. R. 22, 18333, 2015.

146.PARK C.M., CHU K.H., HEO J., HER N., JANG M., SON A., YOON Y. Environmental behavior of engineered nanomaterials in porous media: a review. J Hazard Mater. 309, 133, 2016.

147. ZHANG Y., HE Z., WANG H., QI L., LIU G., ZHANG $X$. Applications of hollow nanomaterials in environmental remediation and monitoring: A review. Front. Env. Sci. Eng. 9, 770, 2015.

148.HU H., JI F., XU Y., YU J., LIU Q., CHEN L., ZHANG Q. Reversible and precise self-assembly of janus metalorganosilica nanoparticles through a linker-free approach. ACS Nano. 10, 7323, 2016.

149. HAN C., SUN Q., LI Z., DOU S.X. Thermoelectric enhancement of different kinds of metal chalcogenides. Adv. Energy Mater. 6, Article number 1600498, 2016.

150. CEA P., MARTÍN S., GONZÁLEZ-ORIVE A., OSORIO H.M., QUINTÍN P., HERRER L. Nanofabrication and electrochemical characterization of self-assembled monolayers sandwiched between metal nanoparticles and electrode surfaces. J. Chem. Educ. 93, 1441, 2016.

151. DONG J., GOLDTHORPE I.A., ABUKHDEIR N.M. Automated quantification of one-dimensional nanostructure alignment on surfaces. Nanotechnology, 27, Article number 235701, 2016.

152.152. GOVINDARAJAN M., HOTI S.L., RAJESWARY M., BENELLI G. One-step synthesis of polydispersed silver nanocrystals using Malva sylvestris: an eco-friendly mosquito larvicide with negligible impact on non-target aquatic organisms. J. Parasitol. Res. 1, Article number 11, 2016.

153. JACKMAN J.A., CHO D.J., LEE J., CHEN J.M., BESENBACHER F., BONNELL D., ACHO N.J. Nanotechnology education for the global world: training the leaders of tomorrow. ACS Nano, 10, 5595, 2016.

154.LI H., DENG Y., LIANG J., DAI Y., LI B., REN Y., LI C. Direct preparation of hollow nanospheres with kraft lignin: A facile strategy for effective utilization of biomass waste. BioResources, 11, 3073, 2016a.

155. LI J., MO L., LU C.H., FU T., YANG H.H., Tan W. Functional nucleic acid-based hydrogels for bioanalytical and biomedical applications. Chem Soc Rev. 45, 1410, 2016b.

156. CINELLI M., COLES S.R., SADIK O., KARN B., KIRWAN K. A framework of criteria for the sustainability assessment of nanoproducts. J. Clean Prod. 126, 277, 2016.

157. ALI TAHIR A., ULLAH H., SUDHAGAR P., ASRI M.T.M., DEVADOSS A., SUNDARAM S. The application of graphene and its derivatives to energy conversion, storage, and environmental and biosensing devices. Chem. Rec. 16, 1591, 2016.

158. LI J., ROZEN I., WANG J. Rocket science at the nanoscale. ACS nano, 10, 5619, 2016c.

159. SCOGNAMIGLIO V., ANTONACCI A., PATROLECCO L., LAMBREVA M.D., LITESCU S.C., GHUGE S.A., REA G. Analytical tools monitoring endocrine disrupting chemicals. Trends Anal Chem. 80, 555, 2016.

160. ELANGO G., ROOPAN S.M. Efficacy of $\mathrm{SnO}_{2}$ nanoparticles toward photocatalytic degradation of methylene blue dye. J. Photochem. Photobiol. B. 155, 34, 2016.

161. BEGUM R., FAROOQI Z.H., KHAN S.R. Poly (N-isopropylacrylamide-Acrylic acid) copolymer microgels for various applications: A Review. Int. J. Polym. Mater. Po. 65, 841, 2016.

162.LI Y., XIN H., LIU X., ZHANG Y., LEI H., LI B. Trapping and detection of nanoparticles and cells using a parallel photonic nanojet array. ACS nano, 10, 5800, 2016.

163. PEREIRA L., MEHBOOB F., STAMS A.J., MOTA M.M., RIJNAARTS H.H., ALVES M.M. Metallic nanoparticles: microbial synthesis and unique properties for biotechnological applications, bioavailability and biotransformation. Crit. Rev. Biotechnol. 35, 114, 2015.

164.BOGDAN J., JACKOWSKA-TRACZ A., ZARZYŃSKA J., PŁAWIŃSKA-CZARNAK J. Chances and limitations of nanosized titanium dioxide practical application in view of its physicochemical properties. Nanoscale Res. Lett. 10, Article number 57, 2015.

165. PETERS R.J., BOUWMEESTER H., GOTTARDO S., AMENTA V., ARENA M., BRANDHOFF P., RAUSCHER H. Nanomaterials for products and application in agriculture, feed and food. Trends Food Sci. Tech. 54, 155, 2016.

166.IBRAHIM R.K., HAYYAN M., ALSAADI M.A., HAYYAN A., IBRAHIM S. Environmental application of nanotechnology: air, soil, and water. Environ. Sci. Pollut. R. 23, 13764, 2016.

167. DADRASNIA A., SALMAH I., EMENIKE C.U., SHAHSAVARI N. Remediation of oil contaminated media using organic material supplementation. Petrol. Sci. Techno. 33, 1030, 2015.

168. HUSEN A., SIDDIQI K.S. Phytosynthesis of nanoparticles: concept, controversy and application. Nanoscale Res. Lett. 9, 1, 2014.

169. FERNÁNDEZ-LLAMOSAS H., CASTRO L., BLÁZQUEZ M.L., DÍAZ E., CARMONA M. Biosynthesis of selenium nanoparticles by Azoarcus sp. Microb Cell Fact. 15, Article number 109, 2016.

170. POLLMANN K., KUTSCHKE S., MATYS S., KOSTUDIS S., HOPFE S., RAFF J. Novel biotechnological approaches for the recovery of metals from primary and secondary resources. Minerals, 6, Articlew number 54, 2016.

171. BEATTIE A.J., HAY M., MAGNUSSON B., DE NYS R., SMEATHERS J., VINCENT J.F. Ecology and bioprospecting. Austral. Ecol. 36, 341, 2011.

172. EMTIAZI G., HEYDARI E., SALEH T. Oxidation of toxic methyl tert-butyl ether (MTBE) by fungi and nanofilter. Jundishapur J.Microbiol. 3, 99, 2010.

173. BOZARTH A., MAIER U.G., ZAUNER S. Diatoms in biotechnology: modern tools and applications. Appl. Microbiol. Biotechnol. 82, 195, 2009. 
174. JUWARKAR A.A., SINGH S.K., MUDHOO A. A comprehensive overview of elements in bioremediation. Rev. Environ. Sci. Bio. 9, 215, 2010.

175. CALVANTE A. Taller de sustentabilidad. México. Available on line at: http://tallerde,sustentabilidad.ced. cl/wp/wp-content/uploads/2015/04/UAIS-El-conceptomoderno-de-sustentabilidad.pdf. (Accessed September 30, 2016). 2016.

176.LV J., WU J., ZHANG C., LUO Y. Preparing nano magnesium hydroxide-nitrogen doped porous carbon complex material using seaweed biomass useful in remediation of contaminated environment, comprises soaking of seaweed biomass in magnesium ion-urea solution. Patent Number: CN106475052-A, 2017.

177. MING G., QUIN Y., NIU X., REN F., WU H., SUN Z., WANG D., WANG Z., ZHANG C. Soil conditioning agent for remediation of soil contaminated by heavy metal, involves dissolving soluble starch in water, adding water-soluble nano-silica, adding attapulgite powder and immersing cordierite honeycomb in calcium nitrate. Patent Number: CN105950155-A, 2016a.

178. MING G., QUIN Y., NIU X., REN F., WU H., SUN Z., WANG D., WANG Z., ZHANG C. Heavy metal soil repairing agent for remediation of heavy metal pollution in soil, contains attapulgite clay, polyamide fiber, sodium humate, metal chelating agent, biological carbon, polyferric chloride, peat, and calcium peroxide. Patent Number: CN105950180-A, 2016b.

179. MING G., QUIN Y., NIU X., REN F., WU H., SUN Z., WANG D., WANG Z., ZHANG C. Attapulgite nanocomposite repairing agent used in e.g. ecological restoration projects in mining areas, contains attapulgite powder, lime powder, hydroxyapatite, nano-silica, gravel, activated carbon, and calcium peroxide. Patent Number: CN105950181-A, 2016c.

180. CHAI L., WANG H., TANG Z., YANG Z., YANG W., LIANG L., SHI W. Microbial assembly synthesis method for preparation of arsenic-contaminated soil remediation fixing agent, involves activating and culturing filamentous fungi, and dispersing alpha-ferric oxide nanoparticles in liquid medium. Patent Number: CN105733593-A, 2016a.

181. CHAI L., LI Q., WANG H., TANG C., YANG Z., WANG Q., LIANG L., SHI W. Method for preparation of ironbased bio-char material used for remediation of arsenicpolluted soil, involves activating and culturing filamentous fungi and dispersing alpha-ferric oxide nanoparticles in liquid medium. Patent Number: CN105733588-A, 2016b.

182. CHAI L., WANG H., TANG C., YANG Z., LIAO Q., LIANG L., SHI W., DENG N. Application of microbial-based assembly synthetic lead-contaminated soil remediation fixing agent. Patent Number: CN105647539-A, 2016c.

183. CHAI L., LI Q., MIN X., WANG H., TANG C., YANG Z., LIANG L., SHI W. Method for preparing phosphorusbased bio-carbon material for remediation of cadmium contaminated soil, involves utilizing culture medium of filamentous fungus, adding hydroxyapatite nanoparticle followed by inoculating, shaking and drying. Patent Number: CN105598158-A, 2016d.

184.LI J., LIU X. Remediation method of contaminated site involves coating surface of zerovalent nano iron with organic polymer layer, injecting coated nano iron into contaminated soil, oxidizing and injecting bacterium solution into contaminated soil. Patent Number: CN104801540-A, 2015a.
185. LI J., LIU X. Method for determining content of effective iron in nano zero-valent iron particle that is utilized for remediating contaminated sites, involves preparing azo dye solution concentration gradient, followed by using spectrometer. Patent Number: CN104807762-A, 2015b.

186.LI J., LIU X. Magnetic nano-material used for heavy metal contaminated soil remediation, has organic matter cladding layer that is provided outside core, while cladding layer is fibrous radially distributed on surface of particle. Patent Number: CN104801534-A, 2015c.

187. CHENG G., ZHONG Y. Soil remediation nano-material contains bentonite, fly ash, magnesium nitrate, barium oxide nanoparticles, polymeric ferric aluminum silicate, stachydrine, dimethylol urea calcium aluminate, magnesium aluminosilicate and phospholipid. Patent Number: CN105505397-A, 2015a.

188. CHENG G., ZHONG Y. Lead ion contaminated soil remediation agent comprises bentonite, diatomite, wollastonite, polyaluminum ferric silicate, magnesium zinc ferrite, dibasic calcium phosphate dihydrate, nanomagnesium oxide and potassium fluorozirconate. Patent Number: CN105505398-A, 2015b.

189. CHENG G., ZHONG Y. Copper ion contaminated soil remediation agent comprises coal ash, bentonite, diatomite, polyaluminum ferric chloride, calcium aluminate, calcium oxide, plant ash, triazine trisodium salt, nano-zinc oxide and potassium humate. Patent Number: CN105441082-A, 2015c.

190. FANG Z., YANG Z. Preparation of composite material used for remediation of lead-contaminated soil, involves dispersing nano hydroxyapatite in water, mixing potassium chloride and agricultural waste and performing pyrolysis process. Patent Number: CN105131960-A, 2015.

191. FANG Z., SU H. Preparation of biochar particles used in preparing load type zero value nano-iron particles for insitu remediation of chromium-contaminated soil by drying agricultural waste, carrying out deoxy-carbonization, grinding, and sieving. Patent Number: CN105013811-A, 2015.

192.FANG Z., XIE Y. Method for preparing dispersed nanometer nickel/iron bimetallic particles that are utilized to in-situ remediation of poly brominated diphenyl ethers polluted soil, involves mixing iron salt, and polyvinyl pyrrolidone, followed by drying. Patent Number: CN103157810-A, 2013.

193. FENG X., LI M., LIANG R., XIANG Y., GENG L. Ecological slope protection for remediation treatment of e.g. domestic sewage, has multilayered ecological bag filled with nanocomposite material comprising heavy metal-removing material and total phosphorus-removing material. Patent Number: CN106430598-A, 2016a.

194. FENG X., LI M., LIANG R., XIANG Y., GENG L. Black and shrimp water remediation treatment ecological slope protection device has ecological bag whose bottom portion is provided with reinforced screen, and which is provided with multifunctional nano-material composite layer. Patent Number: CN206051687-U, 2016b.

195.BEZBARUAH A., ALMEELBI T.B., QUAMME M., KAHN E., KHAN E. Removing contaminant from aqueous medium involves contacting aqueous medium with remediation material comprising bare nanoscale zero-valent iron particles or calcium-alginate entrapped nanoscale zero-valent iron. Patent Number: WO2014168728-A1, 2015.

196. CHISHOLM B.J., BEZBARUAH A., KALITA H., CHISHOLM B. New functionalized amphiphilic 
plant-based copolymers used e.g. in composition for coating article, as dispersal and suspension agents, for environmental remediation, as solubilizers, detergents, paper coatings and pigment dispersants. Patent Number: WO2013173734-A1, 2014.

197. CHEN M., WANG X., WANG R., ZHANG J., LI X. Remediating agent used for heavy metal lead-cadmium and lead-cadmium sulfide composite contaminated soil, preferably mine soil or agricultural land, comprises modified carbon nanotubes, modified clay mineral and lime. Patent Number: CN104893732-A, 2015.

198. GAO W., HAN L., QIAN L., YAN J., CHEN M. Method for degrading organic pollutant of persulfate in water, involves utilizing activator composite material, adding water with organic pollutants with activating agent and carbon, followed by adding ammonium sulfate with material. Patent Number: CN104129841-A, 2014. 